\title{
Production of Phenols from Lignin-derived Slurry Liquid using Iron Oxide Catalyst
}

5 Takuya Yoshikawa ${ }^{\mathrm{a}, \mathrm{c}}$, Satoshi Shinohara ${ }^{\mathrm{a}}$, Taichi Yagi ${ }^{\mathrm{a}}$, Naonori Ryumon ${ }^{\mathrm{b}}$, Yuta Nakasaka ${ }^{\mathrm{a}}$, Teruoki Tago $^{\mathrm{a}, *}$, and Takao Masuda ${ }^{\mathrm{a}}$

${ }^{a}$ Research Group of Chemical Engineering, Division of Chemical Process Engineering,

Faculty of Engineering, Hokkaido University,

10 N13W8, Kita-ku, Sapporo, Hokkaido 060-8628, Japan

${ }^{\mathrm{b}}$ Idemitsu Kosan Co., Ltd., Advanced Technology Research Laboratories, 1280 Kami-izumi, Sodegaura, Chiba 299-0293, Japan

${ }^{c}$ Research Fellow of the Japan Society for the Promotion of Science

15

* Corresponding author.

E-mail:tago@eng.hokudai.ac.jp

Tel: $+81-11-706-6551$

Fax: +81-11-706-6552 


\begin{abstract}
A two-step process consisting of depolymerization and catalytic cracking without hydrogen addition was carried out to produce phenols from lignin. In the first step, lignin was depolymerized using a silica-alumina catalyst in a water/1-butanol solution at $623 \mathrm{~K}$ for $2 \mathrm{~h}$. After the reaction, lignin-derived slurry liquid was obtained in $67 \mathrm{C}$-mol\% yield. From the model studies, it was considered that lignin was mainly depolymerized via hydrolysis of aryl ether bonds between lignin units. For the second step, the catalytic reaction of the 1-butanol phase of the slurry liquid was carried out over an iron oxide catalyst using a high

10 pressure fixed-bed flow reactor at $673 \mathrm{~K}$. The catalytic reaction under high pressure steam conditions was effective for the suppression of the formation of solid products. In addition, the recovery fraction of phenols increased as the $F_{\mathrm{H} 2 \mathrm{O}} / F$ value (the flow rate ratio of steam to the slurry liquid) increased, resulting in $17 \%$ of phenols at $F_{\mathrm{H} 2 \mathrm{O}} / F=5$ for $2-4 \mathrm{~h}$. From the model studies and our previous results, catechol and methoxyphenol in the slurry liquid were considered to be converted into phenols, cresols and other alkyl phenols over the iron oxide catalyst.
\end{abstract}




\section{$10 \quad$ Keywords}

Biomass utilization, Lignin conversion, Phenols, Iron oxide catalyst, High pressure flow reactor 


\section{Introduction}

From the perspective of fossil fuel depletion and the need to control carbon dioxide emissions, the production of useful chemicals from lignocellulose, which is the most abundant inedible biomass in nature, is becoming increasingly important [1-3].

5 Lignocellulose resources are composed of cellulose, hemicellulose and lignin. Recently, the production of bio-ethanol from cellulose and hemicellulose has been developed worldwide [4]. In these production processes, lignin is removed as an undesired byproduct. In addition, the chemical pulping industry conventionally excretes a large quantity of black liquor containing lignin and inorganic chemicals for treating lignocellulose. The black liquor is typically concentrated and burned in a boiler to produce energy and recover the inorganic chemicals.

Lignin is a high molecular weight polymer composed of methoxylated alkylphenol units. Accordingly, it can be regarded as a rich source of phenols. However, because lignin has a random, three-dimensional network, it is difficult to decompose lignin into phenols. Various methods for the production of phenols from lignin have been investigated, such as hydrolysis [5,6], pyrolysis [7], alkaline oxidation [8-10] and hydrocracking [11-15]. Among these methods, hydrocracking process usually gives good results with respect to the yield of phenols. Because biomass including lignin contains a lot of oxygen, hydrodeoxygenation (HDO) reactions occur during hydrocracking, where oxygen in biomass is removed and converted into $\mathrm{H}_{2} \mathrm{O}$. Recently, hydrodeoxygenation (HDO) of biomass-derived feeds such as bio-oils, lignin and lignin model compounds has been widely studied [16-19].

We previously reported a conversion process for the production of phenols from lignin via two reaction steps, as shown in Figure 1 [20]. Because this process converts lignin without hydrogen using solid catalysts, it is considered to be economically and environmentally promising. First, lignin is depolymerized into lower molecular weight liquid products (referred to as lignin-derived slurry liquid hereafter). For this step of the process, 
lignin hydrolysis was carried out using a solid acid catalyst in a mixture of water/1-butanol, achieving a high yield of the lignin-derived slurry liquid. Although the contact of lignin with a solid catalyst is less efficient than that of lignin with a homogeneous one, the separation and recovery of the used catalyst from the slurry liquid get easier when using a solid catalyst.

5 For this reason, we attempted applying a solid acid catalyst to the depolymerization of lignin. The function of the water/1-butanol solution was assumed to be the extraction of the degraded components such as phenolic compounds and carboxylic acids from the water phase into the 1-butanol phase. Next, the lignin-derived slurry liquid was converted into phenols. Catalytic cracking of the slurry liquid was carried out over an iron oxide catalyst, which we previously developed for converting biomass wastes into useful chemicals [21-24]. This catalyst was applicable to the reaction of the slurry liquid, and the yield of phenols and cresols increased after the catalytic reaction.

Unfortunately, a large quantity of solid products, including carbonaceous residue and coke, were formed after the catalytic cracking of the slurry liquid under a steam atmosphere of 0.1 MPa. It has been reported that hot compressed water, especially supercritical water, can disperse heavy organic molecules $[25,26]$. This property is expected to suppress the polymerization reactions of oligomers and heavy components in the slurry liquid, as well as the formation of carbonaceous residue and coke.

In this study, therefore, the catalytic cracking of lignin-derived slurry liquid was carried out using a fixed-bed flow reactor under high pressure steam conditions, and the effect of reaction conditions on the yield of phenols and solid products was investigated. Moreover, the reaction path of each step in the conversion process was proposed on the basis of reactions using model compounds.

\section{Experimental}

\subsection{Depolymerization of lignin}


Depolymerization of lignin was carried out in an autoclave reactor made of Hastelloy alloy C-276 (KH-50; Hiro Co., Ltd.) with an inner volume of $36 \mathrm{~cm}^{3}$ at $623 \mathrm{~K}$ for $2 \mathrm{~h}$. Figure 2 shows the schematic of the autoclave reactor. Lignin (alkaline) (Tokyo Chemical Industry, abbreviated as lignin), silica-alumina with a $\mathrm{Si} / \mathrm{Al}=2$ (atomic ratio) $(\mathrm{N} 631 \mathrm{HN}$; Nikki

5 Chemical Co., Ltd.) and a mixed solution of distilled water $\left(\mathrm{H}_{2} \mathrm{O}\right)$ and 1-butanol $(\mathrm{BuOH})$ were placed in the reactor. The weights of lignin, silica-alumina and solvent were $0.7 \mathrm{~g}, 0.7 \mathrm{~g}$, and $21 \mathrm{~g}$, respectively, and the composition of solvent was $\mathrm{H}_{2} \mathrm{O} / \mathrm{BuOH}=4$ (molar ratio). The reactor was moved back and forth during the reaction.

Figure 3 shows the analytical procedure for the depolymerization reaction of lignin. 10 After termination of the reaction, the gaseous products were collected with a gas pack, and the remains in the reactor were filtered to recover the lignin-derived slurry liquid and any solid products. The gaseous products were analyzed using gas chromatographs with a thermal conductivity detector (GC-8A; Shimadzu Co., Ltd.) equipped with an activated charcoal column, and a flame ionization detector (GS-20B; Shimadzu Co., Ltd.) equipped with a Porapak Q column. The lignin-derived slurry liquid was analyzed using two gas chromatographs with a flame ionization detector (GC-2014; Shimadzu Co., Ltd.) and two gas chromatograph-mass spectrometers (GC-17A GCMS-QP5050 and GC-2010 GCMS-QP2010 PARVUM2; Shimadzu Co., Ltd.). Gas chromatographs were equipped with capillary columns (DB-Wax and DB-5; J\&W Scientific), and gas chromatograph-mass

20 spectrometers were equipped with the same columns. Thermal analysis of the slurry liquid was carried out under a nitrogen atmosphere with a thermal gravimetric analyzer (TGA-50; Shimadzu Co. Ltd.). The temperature program was set as follows: after holding at $323 \mathrm{~K}$ for $1 \mathrm{~h}$ to remove solvent in the slurry liquid, heating was carried out from $323 \mathrm{~K}$ to $873 \mathrm{~K}$ at a rate of $5 \mathrm{~K} / \mathrm{min}$. The carbon content of the solid product, which consisted of a mixture of the coke deposited on the catalyst and the residue, was analyzed using an elemental analyzer (ECS 4010; Costech Instruments). 
The carbon yield of the products after lignin depolymerization was calculated based on carbon content of lignin originally placed into the autoclave reactor. The carbon content of lignin was analyzed using an elemental analyzer, and was found to be $51.1 \mathrm{wt} \%$.

\subsection{Reactions of model compounds}

To examine the reaction path during lignin depolymerization, reactions using model compounds were carried out. The model compounds were selected due to their structural similarity to lignin. Linkages between the units of lignin are broadly divided into two categories: an ether bond-type and a carbon-carbon bond, namely of the condensed-type (non-ether bond-type). The primary inter-unit linkage is the aryl ether bond, accounting for about $50 \%$ of all inter-unit linkages in lignin $[27,28]$. Figure 4 shows the model compounds used in this study. $p$-Propylphenol, phenethyl phenyl ether (2-phenylethyl phenyl ether), and 2-methoxy-4-methylphenol are the model compounds containing the condensed-type linkage, aryl ether bond, and methoxy group, respectively.

The reactions of these model compounds were carried out in the above-mentioned autoclave reactor, and the reaction conditions were the same as those of lignin depolymerization except for the amount of feedstock. The amount of each model compound placed into the reactor was $1.5 \times 10^{-2} \mathrm{~mol}$. The reaction without any catalyst was also conducted. The analytical procedure was the same as described in Section 2.1.

\subsection{Preparation and characterization of the iron oxide catalyst}

The iron oxide catalyst was prepared by the co-precipitation method. $10 \mathrm{wt} \%$ of ammonia solution was added to aqueous solutions of $\mathrm{Ce}\left(\mathrm{NO}_{3}\right)_{3} \cdot 6 \mathrm{H}_{2} \mathrm{O}, \mathrm{ZrO}\left(\mathrm{NO}_{3}\right)_{2} \cdot 2 \mathrm{H}_{2} \mathrm{O}$, $\mathrm{Al}\left(\mathrm{NO}_{3}\right)_{3} \cdot 9 \mathrm{H}_{2} \mathrm{O}$, and $\mathrm{Fe}\left(\mathrm{NO}_{3}\right)_{3} \cdot 9 \mathrm{H}_{2} \mathrm{O}$ until the $\mathrm{pH}$ reached 7. All reagents were purchased from Wako Pure Chemical Industries (Japan) and were used without further purification. The precipitate was filtered and oven-dried at $383 \mathrm{~K}$ overnight to obtain the catalyst precursor, 
which was subsequently calcined at $773 \mathrm{~K}$ for $2 \mathrm{~h}$ in an air atmosphere. The obtained catalyst is denoted as $\mathrm{CeO}_{2}-\mathrm{ZrO}_{2}-\mathrm{Al}_{2} \mathrm{O}_{3}-\mathrm{FeO}_{\mathrm{X}}$ hereafter. The iron oxide catalyst containing only $\mathrm{ZrO}_{2}$ and $\mathrm{FeO}_{\mathrm{X}}$ (abbreviated as $\mathrm{ZrO}_{2}-\mathrm{FeO}_{\mathrm{X}}$ ) was also prepared by the same method as applied to $\mathrm{CeO}_{2}-\mathrm{ZrO}_{2}-\mathrm{Al}_{2} \mathrm{O}_{3}-\mathrm{FeO}_{\mathrm{X}}$. The content of each component in these catalysts was analyzed by X-ray fluorescence (XRF Supermini; Rigaku Co., Ltd.) and was found to be 6 wt $\% \mathrm{CeO}_{2}, 6$ wt $\% \mathrm{ZrO}_{2}$ and 4 wt $\% \mathrm{Al}_{2} \mathrm{O}_{3}$ in $\mathrm{CeO}_{2}-\mathrm{ZrO}_{2}-\mathrm{Al}_{2} \mathrm{O}_{3}-\mathrm{FeO}_{\mathrm{x}}$, and $7 \mathrm{wt} \% \mathrm{ZrO}_{2}$ in $\mathrm{ZrO}_{2}-\mathrm{FeO}_{\mathrm{X}}$. The structure of the catalyst was analyzed with an $\mathrm{X}$-ray diffractometer (JDX-9020; JEOL).

\subsection{Catalytic cracking of the lignin-derived slurry liquid over $\mathrm{CeO}_{2}-\mathrm{ZrO}_{2}-\mathrm{Al}_{2} \mathrm{O}_{3}-\mathrm{FeO}_{\mathrm{x}}$}

Because the slurry liquid consisted of two phases (water and $\mathrm{BuOH}$ phases) and almost all of the phenols analyzed by gas chromatography were found in the $\mathrm{BuOH}$ phase, the $\mathrm{BuOH}$ phase was used as the feedstock for the catalytic cracking over $\mathrm{CeO}_{2}-\mathrm{ZrO}_{2}-\mathrm{Al}_{2} \mathrm{O}_{3}-\mathrm{FeO}_{\mathrm{X}}$ using a high pressure fixed-bed flow reactor. Because the process of removing solvent from the $\mathrm{BuOH}$ phase could lead to the loss of phenols in the slurry liquid, the $\mathrm{BuOH}$ phase was used without removing the solvent. Figure 5 shows the schematic of the reaction apparatus. Prior to the reaction, the catalyst was preheated under steam flow at reaction temperature under $15 \mathrm{MPa}$ for $1 \mathrm{~h}$. The reaction temperature was fixed at $673 \mathrm{~K}$, and reaction time was varied between 2 and $4 \mathrm{~h}$. The time factor $W / F$ was 0.5 h, where $W$ is the amount of catalyst (g) and $F$ is the flow rate of the slurry liquid (g/h). $F_{\mathrm{H} 2 \mathrm{O}} / F$, where $F_{\mathrm{H} 2 \mathrm{O}}$ is the flow rate of steam, was varied between 2.5 and 7.5.

After the termination of the reaction, the liquid and gaseous products were collected with an ice trap and a gas pack, respectively. The liquid and gas products were analyzed using the same gas chromatographs and gas chromatograph-mass spectrometers as those used for the analysis of the lignin-derived slurry liquid (see Section 2.1.). In this study, as shown in Figure 5, the residue deposited on the inner wall of the reactor was divided into 
three parts to analyze: (i) front of catalyst bed, (ii) reactor, and (iii) behind catalyst bed. The reactor was oven-dried at $383 \mathrm{~K}$ overnight, then the used catalyst was collected, and the weight of each part of the reactor was measured. The carbon content of the residue was calculated based on the assumption that the residue was composed of $(\mathrm{CH})_{\mathrm{n}}$ units using the following equations:

$$
\begin{aligned}
& \text { carboncontentof residue } \\
& \qquad=\frac{\text { weight increaseof thereactorafterthereaction }}{\text { molecularweight of } \mathrm{CH} / \text { carbonmolsin } \mathrm{CH} \text { unit }}
\end{aligned}
$$

The carbon content of the coke on the used catalyst was analyzed using an elemental analyzer (ECS 4010; Costech Instruments).

\subsection{Catalytic cracking of model compounds over iron oxide catalyst}

To elucidate the reaction path for catalytic cracking of the slurry liquid, the reactions using model compounds over $\mathrm{CeO}_{2}-\mathrm{ZrO}_{2}-\mathrm{Al}_{2} \mathrm{O}_{3}-\mathrm{FeO}_{\mathrm{X}}$ and $\mathrm{ZrO}_{2}-\mathrm{FeO}_{\mathrm{X}}$ were conducted. 5 wt\% of catechol or phenol water solution was fed into the fixed-bed flow reactor at $673 \mathrm{~K}$ for $2 \mathrm{~h}$ under atmospheric pressure. The details of the reaction apparatus were described in

15 our previous studies [23,24]. $W / F_{\text {model }}$ was varied between 0 and $4 \mathrm{~h}$, where $F_{\text {model }}$ is the flow rate of the model compound $(\mathrm{g} / \mathrm{h})$. The liquid and gas products were analyzed using the same gas chromatographs and gas chromatograph-mass spectrometers as those used for the analysis of the lignin-derived slurry liquid (see Section 2.1.). The carbon content of the coke on the used catalyst was analyzed using an elemental analyzer (ECS 4010; Costech 20 Instruments).

\section{Results and Discussion}

\subsection{Depolymerization of lignin}

\subsubsection{Results of lignin depolymerization}


Depolymerization of lignin was carried out in $\mathrm{H}_{2} \mathrm{O} / \mathrm{BuOH}$ solution using silica-alumina at $623 \mathrm{~K}$ for $2 \mathrm{~h}$. Figure 6 shows the yield of lignin-derived slurry liquid after the reaction, and Table 1 shows the recovery fraction of phenols from the $\mathrm{BuOH}$ phase of the slurry liquid. Because the lignin used in this study was found to be sulfite lignin on the basis of the data registered in the National Institute of Technology and Evaluation of Japan, the recovery fraction was calculated based on the assumption that the constituent monomer of lignin was 2-methoxy-4-(2,3-dihydroxy-1-sulfo)-propylphenol. The recovery fractions were obtained using the following equations:

$$
\begin{aligned}
& \text { molsof aromatioringin lignin } \\
& =\frac{\text { weight of lignin used for thedepolymeriationreaction }}{\text { molecularweight of constituet monomer }} \\
& \text { molsof aromatioringin phenolsafterthedepolymeriationreaction } \\
& =\frac{\text { carbonmolsof theobtainedphenols }}{\text { carbonnumbersin onemolecularof thephenols }}
\end{aligned}
$$$$
10
$$

From equation (2), the mols of aromatic ring in lignin placed in the autoclave reactor was calculated using the basic unit of lignin, and from equation (3), mols of aromatic ring in phenols were calculated based on the GC analysis results obtained after the depolymerization reaction. From (2) and (3),

$$
\text { recovery fractionof phenols } \%=\frac{\text { molsof aromatioring in phenols }}{\text { molsof aromatioringin lignin }} \times 100
$$

From Table 1, it was found that the slurry liquid mainly contained methoxyphenols and catechols.

Figure 7 shows the results of the TGA analyses of lignin and $\mathrm{BuOH}$ phase of the slurry liquids. The $\mathrm{BuOH}$ phase of the slurry liquid was dark brown, while the water phase, in contrast, was a nearly colorless and transparent solution. Accordingly it was determined that the lignin-derived products were mainly contained in the $\mathrm{BuOH}$ phase, and TGA analysis was conducted using the $\mathrm{BuOH}$ phase. The weight loss curves of the lignin-derived products in the $\mathrm{BuOH}$ phase shifted to the lower temperature region as compared with that of raw 
lignin. Weight loss of a sample in the lower temperature region of a TGA analysis indicates that the sample consists of chemicals with lower molecular weights. Accordingly, this shift indicated that the lignin-derived products became lighter and depolymerization of lignin proceeded.

\subsubsection{Investigation of the reaction path based on the results using model compounds}

To elucidate the reaction path of lignin depolymerization, the reactions of model compounds shown in Fig. 4 were carried out. After the reaction of p-propylphenol, no decomposition of the propyl group (e.g., production of phenol, p-cresol or p-ethylphenol) was observed. This indicated that the decomposition of the condensed-type linkage between lignin units rarely occurred during lignin depolymerization.

Figure 8 (a) shows the yield of identified products by GC after the reaction of phenethyl phenyl ether, and Table 2 (a) shows the product yields after the reaction. The yields of unidentified and undetectable products by GC in Table 2 were calculated by the difference using the following equation:

$$
\begin{aligned}
& \text { Unidentified and undetectable products by GC /C - mol\% } \\
& \qquad=100-(\text { Unreacted model compound + Identified products by GC + Coke) }
\end{aligned}
$$

Without catalyst, decomposition of the aryl ether bond proceeded only slightly, and a small amount of phenol and styrene were produced. These products were also observed in other studies on pyrolysis of phenethyl phenyl ether [29,30]. With the silica-alumina catalyst, the conversion of the model compound increased considerably, and phenol and phenethyl alcohol were selectively produced. Because it was reported that aryl ether bonds were hydrolyzed by acid catalysts such as hydrochloric acid [31,32], hydrolysis of phenethyl phenyl ether over silica-alumina was considered to produce phenol and phenethyl alcohol. Alkylphenols, e.g., butylphenol, were the major products, and various alkylbenzenes were also produced. Because this reaction was carried out in $\mathrm{H}_{2} \mathrm{O} / \mathrm{BuOH}$ solution, consecutive 
alkylations of the obtained phenol or phenethyl alcohol with $\mathrm{BuOH}$ were considered to produce these compounds.

Figure 8 (b) shows the yield of identified products by GC after the reaction of 2-methoxy-4-methylphenol, and Table 2 (b) shows the product yields after the reaction.

5 Without catalyst, 4-methyl-catechol was selectively produced. This result indicated that the methoxy group was thermally decomposed. With the silica-alumina catalyst, the conversion of the model compound increased whereas the yield of 4-methyl-catechol decreased, and other catechols including tert-butylcatechol and methyl propionyl catechol were produced. The formation of methanol indicated that the methoxy group was possibly decomposed via hydrolysis. The other catechols were considered to be formed by the alkylation of the obtained 4-methyl-catechol with $\mathrm{BuOH}$ and/or the produced methanol.

These results indicated that the depolymerization of lignin mainly proceeded via hydrolysis of aryl ether bonds between lignin units, which is the primary linkage between lignin units, producing phenols, cresols, methoxyphenols and alkyl phenols in the slurry liquid. In addition, catechols were mainly produced via thermal decomposition of methoxy groups in methoxyphenols during lignin depolymerization.

\subsection{Catalytic cracking of lignin-derived slurry liquid over $\mathrm{CeO}_{2}-\mathrm{ZrO}_{2}-\mathrm{Al}_{2} \mathrm{O}_{3}-\mathrm{FeO}_{\mathrm{X}}$}

\subsubsection{Effect of reaction pressure}

We previously developed iron oxide catalysts including $\mathrm{ZrO}_{2}-\mathrm{FeO}_{\mathrm{X}}$ and $\mathrm{ZrO}_{2}-\mathrm{Al}_{2} \mathrm{O}_{3}-\mathrm{FeO}_{\mathrm{X}}$. From the results of our previous studies, the functions of each component in the catalysts were summarized as follows: The organics adsorbed on the iron oxide-based catalyst were oxidatively decomposed using the lattice oxygen in $\mathrm{FeO}_{\mathrm{X}}$. Because $\mathrm{ZrO}_{2}$ exhibits activity to produce active oxygen species from $\mathrm{H}_{2} \mathrm{O}$, the defects of oxygen in $\mathrm{FeO}_{\mathrm{X}}$ can be regenerated by the active oxygen species [33, 34]. The addition of $\mathrm{Al}_{2} \mathrm{O}_{3}$ was effective for the decrease in the $\mathrm{FeO}_{\mathrm{X}}$ domain size, and the increase in the surface 
area of the catalyst $[34,35]$. The composition of $\mathrm{ZrO}_{2}-\mathrm{Al}_{2} \mathrm{O}_{3}-\mathrm{FeO}_{\mathrm{X}}$ was investigated and optimized for the upgrading of petroleum residual oil [34]. Because $\mathrm{CeO}_{2}$ has a hydrophilic property and a high oxygen storage capacity, it was expected that $\mathrm{CeO}_{2}$ as well as $\mathrm{ZrO}_{2}$ enhanced the production of active oxygen species from $\mathrm{H}_{2} \mathrm{O}$. For this reason, catalytic cracking of the slurry liquid was carried out over $\mathrm{CeO}_{2}-\mathrm{ZrO}_{2}-\mathrm{Al}_{2} \mathrm{O}_{3}-\mathrm{FeO}_{\mathrm{x}}$.

As mentioned in Section 2.4, the BuOH phase of the slurry liquid was used as feedstock for the catalytic cracking without removal of the solvent. We previously reported that the partial oxidation of alcohols occurred to produce carboxylic acids, followed by the ketonization of the carboxylic acids over the iron oxide catalyst $[23,24,36]$. In addition, it was confirmed that the catalytic reaction of $\mathrm{BuOH}$ alone over $\mathrm{CeO}_{2}-\mathrm{ZrO}_{2}-\mathrm{Al}_{2} \mathrm{O}_{3}-\mathrm{FeO}_{\mathrm{X}}$ did not produce any phenols. Accordingly, this study focused on phenols among whole products after the reaction. In this study, the recovery fraction of phenols was calculated using equations (2)-(4) on the basis of the amount of lignin used for the depolymerization reaction.

Catalytic cracking of the lignin-derived slurry liquid was carried out under different pressures at $F_{\mathrm{H} 2 \mathrm{O}} / F=2.5$. Figure 9 shows the recovery fractions of phenols after the catalytic reactions. The recovery fraction of phenols under pressurized steam conditions slightly increased compared to that under $0.1 \mathrm{MPa}$. With respect to the composition of phenols, catechols and methoxyphenols drastically decreased, whereas phenols, cresols and alkylphenols comprised of butylphenol and ethylphenol as major products increased after the catalytic reaction of the slurry liquid. A small amount of other mono-aromatics including dimethyl phenyl acetate, propoxy benzaldehyde, and methoxy phenyl acetone were also produced. This reaction path of phenols over $\mathrm{CeO}_{2}-\mathrm{ZrO}_{2}-\mathrm{Al}_{2} \mathrm{O}_{3}-\mathrm{FeO}$ is discussed in Section 3.2.3.

Table 3 shows the yield of solid products including the residue and coke. The total yield of solid products decreased as the reaction pressure increased. Oligomers and heavy components in the slurry liquid were polymerized by heating in the electric furnace before 
reaching the catalyst bed under an atmospheric pressure, followed by the formation of a significant amount of carbonaceous residue. In contrast, it was reported that supercritical water had the effect of dispersing heavy components in oil sand bitumen, leading to the prevention of recombination reactions for upgrading oil sand bitumen [26]. It was considered that a similar effect under high pressure steam conditions suppressed the polymerization reactions of the heavy components in the slurry liquid. As shown in Table 3, the amount of residue in front of the catalyst bed significantly decreased under high pressure steam conditions. This meant that the amount of oligomers and heavy components contacting $\mathrm{CeO}_{2}-\mathrm{ZrO}_{2}-\mathrm{Al}_{2} \mathrm{O}_{3}-\mathrm{FeO}_{\mathrm{X}}$ increased with increasing reaction pressure. On the other hand, the amount of coke on the catalyst was nearly constant at every reaction pressure. These results indicated that the tendency for coke deposition on the catalyst declined as the reaction pressure increased. Therefore, the catalytic reaction of the slurry liquid under high pressure was effective for the recovery of phenols and the suppression of the formation of solid products.

\subsubsection{Effect of $F_{\mathrm{H} 2 \mathrm{O}} / F$ value}

Figure 10 shows the recovery fraction of phenols after the reaction of lignin-derived slurry liquid at different $F_{\mathrm{H} 2 \mathrm{O}} / F$ values under $15 \mathrm{MPa}$ for $2-4 \mathrm{~h}$. The recovery fraction of phenols increased slightly as the $F_{\mathrm{H} 2 \mathrm{O}} / F$ value increased after the catalytic reaction for $2 \mathrm{~h}$. Figure 11 shows $\mathrm{XRD}$ patterns of $\mathrm{CeO}_{2}-\mathrm{ZrO}_{2}-\mathrm{Al}_{2} \mathrm{O}_{3}-\mathrm{FeO}_{\mathrm{X}}$ before and after the reactions for $2 \mathrm{~h}$. The XRD pattern before the reaction in Fig. 11 is the one collected after the steam pre-treatment. As described in Section 3.2.1., it was reported that oxidative reactions over iron oxide catalysts consume the lattice oxygen in $\mathrm{FeO}_{\mathrm{X}}$, which can be regenerated by active oxygen species produced from $\mathrm{H}_{2} \mathrm{O}$ over $\mathrm{ZrO}_{2}[33,34]$. Accordingly, the degree of catalyst deactivation was observed by transforming the crystal phase from hematite to magnetite. After the reaction, the catalyst structure at $F_{\mathrm{H} 2 \mathrm{O}} / F=2.5$ included magnetite, whereas the 
catalysts at more than $F_{\mathrm{H} 2 \mathrm{O}} / F=5$ were mostly unchanged and retained their initial hematite content because there was enough steam for the catalytic reaction. Therefore, it can be concluded that the improvement of catalyst stability caused the increase in the recovery fraction of phenols at high $F_{\mathrm{H} 2 \mathrm{O}} / F$ values.

With respect to the reaction time, the recovery fraction of phenols increased as the reaction time increased at $F_{\mathrm{H} 2 \mathrm{O}} / F=5.0-7.5$. Because the reactor was injected with high pressure steam at the beginning of the reaction, the initial period of the catalytic reaction was an unsteady state. In contrast, it was considered that the catalytic reaction between $2-4 \mathrm{~h}$ became more stable, resulting in the increase in the recovery fraction of phenols. Moreover, the total recovery fraction of phenols increased after the reaction at $F_{\mathrm{H} 2 \mathrm{O}} / F=5.0-7.5$ for $2-4$ $\mathrm{h}$ as compared with that of slurry liquid. This indicated that lignin-derived compounds in the slurry liquid were converted into phenols over $\mathrm{CeO}_{2}-\mathrm{ZrO}_{2}-\mathrm{Al}_{2} \mathrm{O}_{3}-\mathrm{FeO}_{\mathrm{X}}$.

\subsubsection{Investigation of the reaction path based on the results using model compounds}

We previously reported that guaiacol (2-methoxyphenol) was selectively converted into phenol over iron oxide catalyst [37]. Therefore, it is considered that demethoxylation of methoxyphenols proceeded via a reaction pathway similar to that involved in the reaction of guaiacol.

In this study, to clarify the reaction path of catechols, catalytic reactions using catechol and phenol as model compounds were carried out over $\mathrm{CeO}_{2}-\mathrm{ZrO}_{2}-\mathrm{Al}_{2} \mathrm{O}_{3}-\mathrm{FeO}_{\mathrm{X}}$ under atmospheric pressure. Figure 12 (a) shows the yield of the detectable products by GC after the reaction of catechol, and Table 4 shows the product yields after the reaction of catechol and phenol. Catechol showed little reaction without catalyst. In contrast, phenol was selectively produced from catechol over $\mathrm{CeO}_{2}-\mathrm{ZrO}_{2}-\mathrm{Al}_{2} \mathrm{O}_{3}-\mathrm{FeO}_{\mathrm{X}}$, and the yield of phenol increased as $W / F_{\text {model }}$ increased. In addition, phenol showed little reaction over $\mathrm{CeO}_{2}-\mathrm{ZrO}_{2}-\mathrm{Al}_{2} \mathrm{O}_{3}-\mathrm{FeO}_{\mathrm{X}}$, and the yield of benzene was only $0.15 \mathrm{C}-\mathrm{mol} \%$. Therefore, these 
results indicated that catechol and methoxyphenol were converted into phenols, cresols and alkyl phenols over $\mathrm{CeO}_{2}-\mathrm{ZrO}_{2}-\mathrm{Al}_{2} \mathrm{O}_{3}-\mathrm{FeO}$.

The catalytic reaction of catechol over $\mathrm{ZrO}_{2}-\mathrm{FeO}_{\mathrm{X}}$ was also carried out at $W / F_{\text {model }}=4$. Figure 12 (b) shows the yield of the detectable products by GC after the reaction. Although the yield of phenol was lower than that obtained using $\mathrm{CeO}_{2}-\mathrm{ZrO}_{2}-\mathrm{Al}_{2} \mathrm{O}_{3}-\mathrm{FeO}_{\mathrm{X}}$, phenol was selectively produced after the reaction over $\mathrm{ZrO}_{2}-\mathrm{FeO}_{\mathrm{X}}$. Accordingly, this result indicated that the main active field of the reaction was over $\mathrm{FeO}_{\mathrm{X}}$.

\section{Conclusions}

A two-step process that consisted of depolymerization and catalytic cracking was carried out to produce phenols from lignin. In the first step, lignin was depolymerized using silica-alumina in a $\mathrm{H}_{2} \mathrm{O} / \mathrm{BuOH}$ solution at $623 \mathrm{~K}$ for $2 \mathrm{~h}$. From the results using model compounds, it was considered that depolymerization of lignin mainly proceeded via hydrolysis of aryl ether bonds between lignin units. For the second step, the catalytic reaction of the $\mathrm{BuOH}$ phase of the slurry liquid was carried out over $\mathrm{CeO}_{2}-\mathrm{ZrO}_{2}-\mathrm{Al}_{2} \mathrm{O}_{3}-\mathrm{FeO}_{\mathrm{X}}$ catalyst using a high pressure fixed-bed flow reactor. Under high pressure steam conditions, the yield of solid products, especially the residue in front of the catalyst bed, greatly decreased as compared to the one under atmospheric pressure. It was considered that polymerization reactions of oligomers and heavy components in the slurry liquid were suppressed under the high pressure steam conditions. In addition, the recovery fraction of phenols increased as the $F_{\mathrm{H} 2 \mathrm{O}} / F$ value increased. The results of analysis of the catalyst structure revealed that the improvement of catalyst stability caused the increase in the recovery fraction of phenols at high $F_{\mathrm{H} 2 \mathrm{O}} / F$ values. Investigation of the reaction path of phenols in the slurry liquid over $\mathrm{CeO}_{2}-\mathrm{ZrO}_{2}-\mathrm{Al}_{2} \mathrm{O}_{3}-\mathrm{FeO}_{\mathrm{X}}$ was also carried out using catechol and phenol as model compounds under atmospheric pressure. From the reaction 
results, it was considered that methoxyphenols and catechols in the slurry liquid were selectively converted into phenols, cresols, and alkylphenols.

\section{Acknowledgements}

This work was supported by the Advanced Low Carbon Technology Research and Development Program (ALCA) from the Japan Science and Technology Agency (JST).

\section{References}

1. A. Demirbaş, Biomass resource facilities and biomass conversion processing for fuels and chemicals, Energy Conversion and Management 42 (2001) 1357-1378

2. E.-J. Ras, B. McKay, G. Rothenberg, Understanding Catalytic Biomass Conversion Through Data Mining, Top Catal 53 (2010) 1202-1208

3. A Corma, S. Iborra, A. Velty, Chemical Routes for the Transformation of Biomass into Chemicals, Chem. Rev. 107 (2007) 2411-2502

4. M. Galbe, G. Zacchi, A review of the production of ethanol from softwood, Appl. Microbiol. Biotechnol. 59 (2002) 618-628

5. S. Karagöz, T. Bhaskar, A. Muto, Y. Sakata, Comparative studies of oil compositions produced from sawdust, rice husk, lignin and cellulose by hydrothermal treatment, Fuel $84(2005) 875-884$

6. F. Bouxin, S. Baumberger, B. Pollet, A. Haudrechy, JH. Renault, P. Dole, Acidolysis of a lignin model: Investigation of heterogeneous catalysis using Montmorillonite clay, F. Bouxin, S. Baumberger, B. Pollet, A. Haudrechy, JH. Renault, P. Dole, Bioresource Technology 101 (2010) 736-744 
7. C. Amen-Chen, H. Pakdel, C. Roy, Production of monomeric phenols by thermochemical conversion: a review, Bioresource Technology 79 (2001) 277-299

8. G. Wu, M. Heitz, E. Chornet, Improved alkaline oxidation process for the production of aldehydes (vanillin and syringaldehyde) from steam-explosion hardwood lignin, Ind. Eng. Chem. Res. 33 (1994) 718-723

9. J. C. Villar, A. Caperos, F. García-Ochoa, Oxidation of hardwood kraft-lignin to phenolic derivatives with oxygen as oxidant, Wood Sci. Technol., 35 (2001) 245-255

10. A.L. Mathias, A.B. Rodrigues, Production of Vanillin by Oxidation of Pine Kraft Lignins with Oxygen, Holzforschung, 49 (1995) 273-278

11. M. Koyama, Hydrocracking of lignin-related model dimers, Bioresource Technology 44 (1993) 209-215

12. R. W. Thring, J. Breau, Hydrocracking of solvolysis lignin in a batch reactor, Fuel 75 (1996) 795-800

13. D. W. Goheen, Hydrocracking of lignin by the Noguchi process, Adv. Chem. Ser., 59 (1966) 205-225

14. F. Davoudzadeh, B. Smith, E. Avni, R. W. Coughlin, Depolymerization of Lignin at Low Pressure Using Lewis Acid Catalysts and under High Pressure Using Hydrogen Donor Solvents, Holzforschung, 39 (1985) 159-166

15. M. Kleinert, T. Barth, Phenols from Lignin, Chem. Eng. Technol., 31 (2008) 736-745

16. E. Furimsky, Catalytic hydrodeoxygenation, Appl. Catal. A-Gen., 199 (2000) 147-190

17. A. Centeno, E. Laurent, B. Delmon, Influence of the Support of CoMo Sulfide Catalysts and of the Addition of Potassium and Platinum on the Catalytic Performances for the Hydrodeoxygenation of Carbonyl, Carboxyl, and Guaiacol-Type Molecules, J. Catal., 154 (1995) 288-298 Conversion of Phenolic Bio-Oil to Alkanes, Angew. Chem., 121 (2009) 4047-4050 
19. H. Ohta, H. Kobayashi, K. Hara, A. Fukuoka, Hydrodeoxygenation of phenols as lignin models under acid-free conditions with carbon-supported platinum catalysts, Chem. Commun., 47 (2011) 12209-12211

20. T. Yoshikawa, T. Yagi, S. Shinohara, T. Fukunaga, Y. Nakasaka, T. Tago, T. Masuda, Production of phenols from lignin via depolymerization and catalytic cracking, Fuel Process. Technol., 108 (2013) 69-75

21. T. Masuda, Y. Kondo, M. Miwa, T. Shimotori, S. R. Mukai, K. Hashimoto, M. Takano, S. Kawasaki, S. Yoshida, Recovery of useful hydrocarbons from oil palm waste using $\mathrm{ZrO}_{2}$ supporting FeOOH catalyst, Chem. Eng. Sci. 56 (2001) 897-904

22. D. Na-Ranong, R. Yuangsawad, T. Tago, T. Masuda, Recovery of useful chemicals from oil palm shell-derived oil using zirconia supporting iron oxide catalysts, Korean J. Chem. Eng. 25 (2008) 426-430

23. S. Funai, T. Tago, T. Masuda, Selective production of ketones from biomass waste containing a large amount of water using an iron oxide catalyst, Catal. Today 164 (2011) 443-446

24. D. Mansur, T. Yoshikawa, K. Norinaga, J. Hayashi, T. Tago, T. Masuda, Production of ketones from pyroligneous acid of woody biomass pyrolysis over an iron-oxide catalyst, Fuel, 103 (2013) 130-134

25. A. Kruse, E. Dinjus, Hot compressed water as reaction medium and reactant Properties and synthesis reactions, J. Supercrit. Fluids, 39 (2007) 362-380

26. M. Morimoto, Y. Sugimoto, Y. Saotome, S. Sato, T. Takanohashi, Effect of supercritical water on upgrading reaction of oil sand bitumen, J. Supercrit. Fluids, 55 (2010) 223-231

27. K.V. Sarkanen, C.H. Ludwig, (Eds.), Lignins: Occurrence, Formation, Structure and Reactions, Wiley-Interscience, New York (1971)

28. E. Adler, Lignin Chemistry-Past, Present and Future, Wood Sci. Technol. 11 (1977) 
$169-218$

29. M.T. Klein, P.S. Vlrk, Model Pathways in Lignin Thermolysis. 1. Phenethyl Phenyl Ether, Ind. Eng. Chem. Fundam., 22 (1983) 35-45

30. P.F. Britt, A.C.Buchanan III, M.J. Cooney, D. R. Martineau, Flash Vacuum Pyrolysis of Methoxy-Substituted Lignin Model Compounds, J. Org. Chem., 65 (2000) 1376-1389

31. YZ Lai, XP Guo, Acid-Catalyzcd Hydrolysis of Non-Cyclic $\alpha$-Aryl Ether Linkages in Wood, Holzforschung, 46 (1992) 311-314

32. M Meshgini, KV Sarkanen, Synthesis and Kinetics of Acid-Catalyzed Hydrolysis of some $\alpha$-Aryl Ether Lignin Model Compounds, Holzforschung, 43 (1989) 239-243

33. E. Fumoto, T. Tago, T. Tsuji, T. Masuda, Energy Fuels, Recovery of useful hydrocarbons from petroleum residual oil by catalytic cracking with steam over zirconia-supporting iron oxide catalyst, 18 (2004) 1770-1774

34. S. Funai, E. Fumoto, T. Tago, T. Masuda, Recovery of useful lighter fuels from petroleum residual oil by oxidative cracking with steam using iron oxide catalyst, Chem. Eng. Sci. 65 (2010) 60-65

35. E. Fumoto, T. Tago, T. Masuda, Production of Lighter Fuels by Cracking Petroleum Residual Oils with Steam over Zirconia-Supporting Iron Oxide Catalysts, Energy Fuels, $20(2006) 1-6$

36. S. Funai, Y. Satoh, Y. Satoh, K. Tajima, T. Tago, T. Masuda, Development of a new conversion process consisting of hydrothermal treatment and catalytic reaction using $\mathrm{ZrO}_{2}-\mathrm{FeO}_{\mathrm{X}}$ catalyst to convert fermentation residue into useful chemicals, Top. Catal., 53 (2010) 654-658

37. T. Yoshikawa, D. Na-Ranong, T. Tago, T. Masuda, Oxidative cracking of aromatic compounds related to lignin constituents with steam using $\mathrm{ZrO}_{2}-\mathrm{Al}_{2} \mathrm{O}_{3}-\mathrm{FeO}_{\mathrm{X}}$ catalyst, $\mathrm{J}$. Jpn. Petrol. Inst. 53 (2010) 178-183 


\section{Figure and Table Captions}

Figure 1. Outline of the process for the production of phenols from lignin.

5 Figure 2. Schematic of the autoclave reactor for the depolymerization of lignin.

Figure 3. Analytical procedure for the depolymerization of lignin.

Figure 4. Structures of the selected model compounds: (a) p-propylphenol, (b) phenethyl 10 phenyl ether, (c) 2-methoxy-4-methylphenol.

Figure 5. Schematic of the high pressure fixed-bed flow reactor for the catalytic cracking.

Figure 6. The yield of lignin-derived slurry liquid after the lignin depolymerization. Reaction conditions: $\mathrm{H}_{2} \mathrm{O} / \mathrm{BuOH}=4$, silica-alumina, $T=623 \mathrm{~K}$, reaction time $=2 \mathrm{~h}$.

Figure 7. Results of TGA analysis of lignin-derived slurry liquid ( $\mathrm{BuOH}$ phase). $\mathrm{W}_{0}$ : The weight after holding at $323 \mathrm{~K}$ for $1 \mathrm{~h}$ under $\mathrm{N}_{2}$ atmosphere.

Figure 8. Yields of the identified products by GC after the reaction of model compounds: (a) phenethyl phenyl ether, (b) 2-methoxy-4-methylphenol. Reaction conditions: $\mathrm{H}_{2} \mathrm{O} / \mathrm{BuOH}=4$, $T=623 \mathrm{~K}$, reaction time $=2 \mathrm{~h}$.

Figure 9. Effect of reaction pressure on the recovery fraction of phenols after the reaction of the slurry liquid. Reaction conditions: $\mathrm{CeO}_{2}-\mathrm{ZrO}_{2}-\mathrm{Al}_{2} \mathrm{O}_{3}-\mathrm{FeO}_{\mathrm{X}}, W / F=0.5 \mathrm{~h}, T=673 \mathrm{~K}$, reaction time $=2 \mathrm{~h}$. 
Figure 10. Effect of $F_{\mathrm{H} 2 \mathrm{O}} / F$ value on the recovery fraction of phenols after the reaction of the slurry liquid. Reaction conditions: $\mathrm{CeO}_{2}-\mathrm{ZrO}_{2}-\mathrm{Al}_{2} \mathrm{O}_{3}-\mathrm{FeO}_{\mathrm{X}}, W / F=0.5 \mathrm{~h}, P=15 \mathrm{MPa}, T=$ $673 \mathrm{~K}$, reaction time $=2-4 \mathrm{~h}$.

Figure 11. XRD patterns of $\mathrm{CeO}_{2}-\mathrm{ZrO}_{2}-\mathrm{Al}_{2} \mathrm{O}_{3}-\mathrm{FeO}_{\mathrm{X}}$ catalysts before and after the reactions of the slurry liquid at different values of $F_{\mathrm{H} 2 \mathrm{O}} / F$. Reaction conditions: $W / F=0.5 \mathrm{~h}, P=15$ $\mathrm{MPa}$, reaction time $=2 \mathrm{~h}$.

10 Figure 12. Yields of the detectable products by GC after the reactions of catechol solution over (a) $\mathrm{CeO}_{2}-\mathrm{ZrO}_{2}-\mathrm{Al}_{2} \mathrm{O}_{3}-\mathrm{FeO}_{\mathrm{X}}$, (b) $\mathrm{ZrO}_{2}-\mathrm{FeO}_{\mathrm{X}}$. Reaction conditions: $T=673 \mathrm{~K}, P=0.1$ $\mathrm{MPa}$, reaction time $=2 \mathrm{~h}$.

Table 1. Recovery fraction of components of phenols in the $\mathrm{BuOH}$ phase of the slurry liquid. 15 Reaction conditions: $\mathrm{H}_{2} \mathrm{O} / \mathrm{BuOH}=4$, silica-alumina, $T=623 \mathrm{~K}$, reaction time $=2 \mathrm{~h}$.

Table 2. Product yields after the reaction of model compounds: (a) phenethyl phenyl ether, (b) 2-methoxy-4-methylphenol. Reaction conditions: $\mathrm{H}_{2} \mathrm{O} / \mathrm{BuOH}=4, T=623 \mathrm{~K}$, reaction time $=2 \mathrm{~h}$.

Table 3. Effect of reaction pressure on the yield of solid products after the reaction of the slurry liquid. Reaction conditions: $\mathrm{CeO}_{2}-\mathrm{ZrO}_{2}-\mathrm{Al}_{2} \mathrm{O}_{3}-\mathrm{FeO}_{\mathrm{X}}, W / F=0.5 \mathrm{~h}, T=673 \mathrm{~K}$, reaction time $=2 \mathrm{~h}$.

25 Table 4. Product yields after the reaction of the solution of model compounds: (a) catechol, (b) phenol. Reaction conditions: $T=673 \mathrm{~K}, P=0.1 \mathrm{MPa}$, reaction time $=2 \mathrm{~h}$. 
Lignin-derived

Lignin $\longrightarrow$ slurry liquid $\longrightarrow$ Phenols partly lignin constituent -monomers and -oligomers

\section{Depolymerization}

$\left(\begin{array}{c}\text { Silica alumina catalyst } \\ \text { In water/1-butanol solution }\end{array}\right)$

\section{Catalytic cracking}

$\left(\begin{array}{c}\text { Iron oxide catalyst } \\ \text { Under steam atmosphere }\end{array}\right)$

Figure 1. Outline of the process for the production of phenols from lignin. 


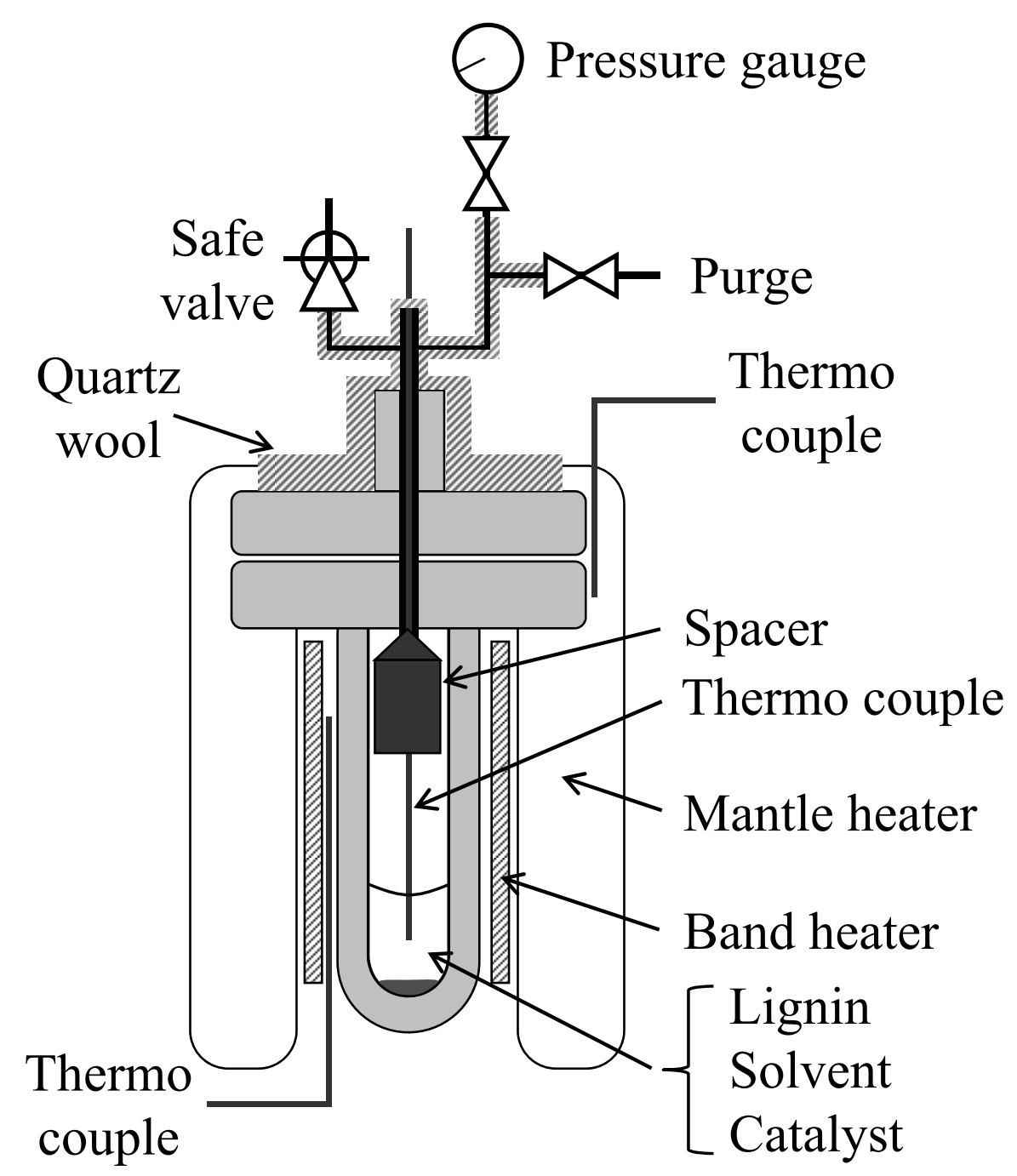

Figure 2. Schematic of the autoclave reactor for the depolymerization of lignin. 


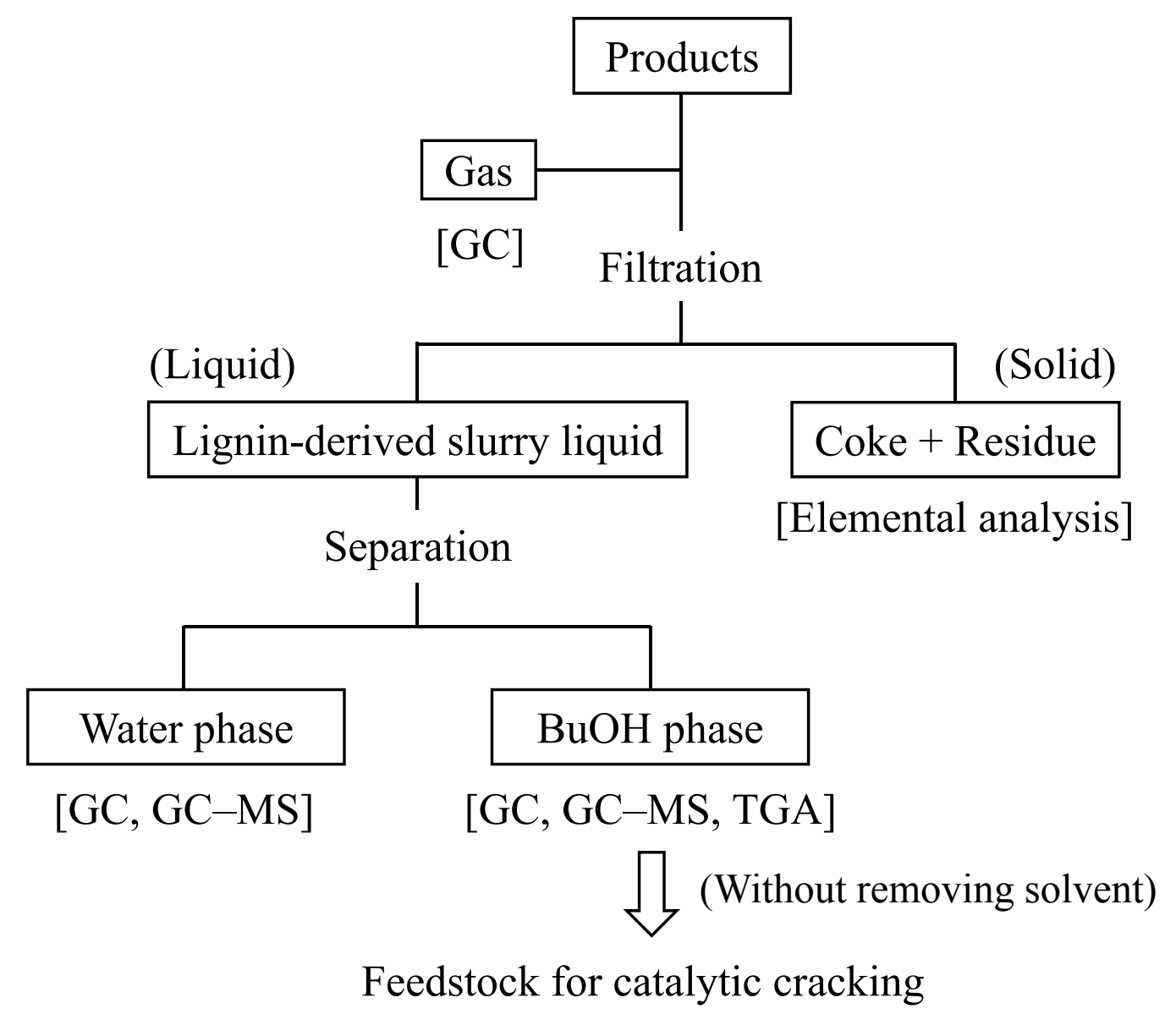

Figure 3. Analytical procedure for the depolymerization of lignin. 
<smiles>CCCc1ccc(O)cc1</smiles>

(a) p-Propylphenol (carbon-carbon bond)<smiles>c1ccc(CCOc2ccccc2)cc1</smiles>

(b) Phenethyl phenyl ether (aryl ether bond)<smiles>COc1cc(C)ccc1O</smiles>

(c) 2-Methoxy-4-methylphenol (methoxy group)

Figure 4. Structures of the selected model compounds:

(a) p-propylphenol, (b) phenethyl phenyl ether, (c) 2-methoxy-4-methylphenol. 


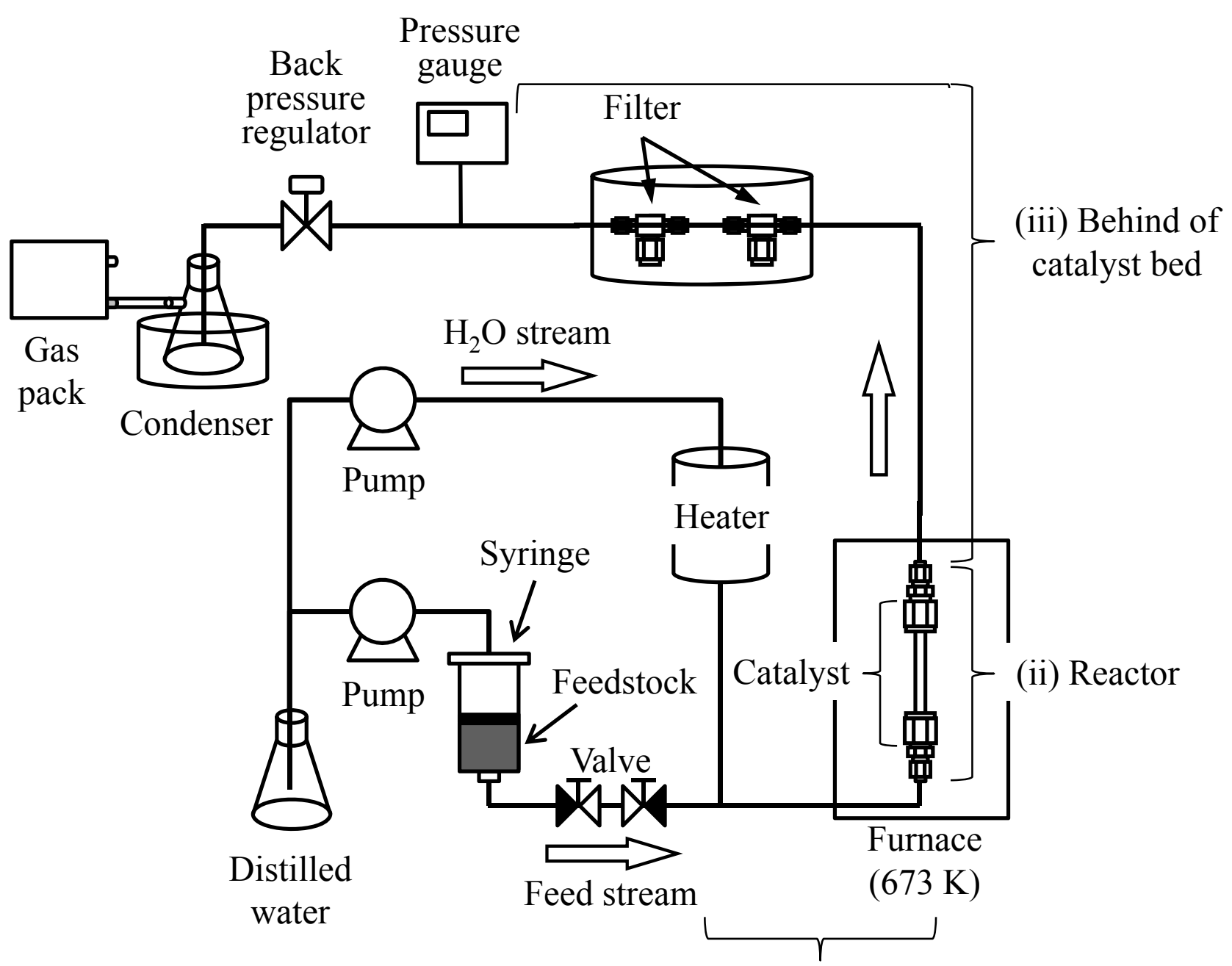

(i) Front of catalyst bed

Figure 5. Schematic of the high pressure fixed-bed flow reactor for the catalytic cracking. 


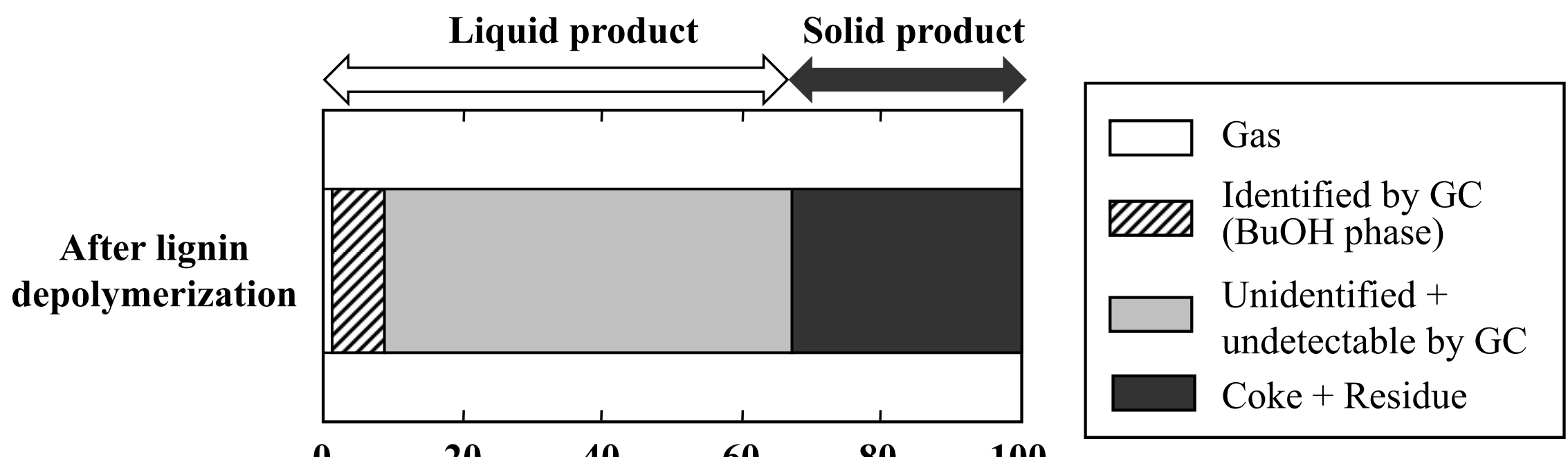

Carbon yield based on lignin /C-mol\%

Figure 6. The yield of lignin-derived slurry liquid after the lignin depolymerization. Reaction conditions: $\mathrm{H}_{2} \mathrm{O} / \mathrm{BuOH}=4$, silica-alumina, $T=623 \mathrm{~K}$, reaction time $=2 \mathrm{~h}$. 


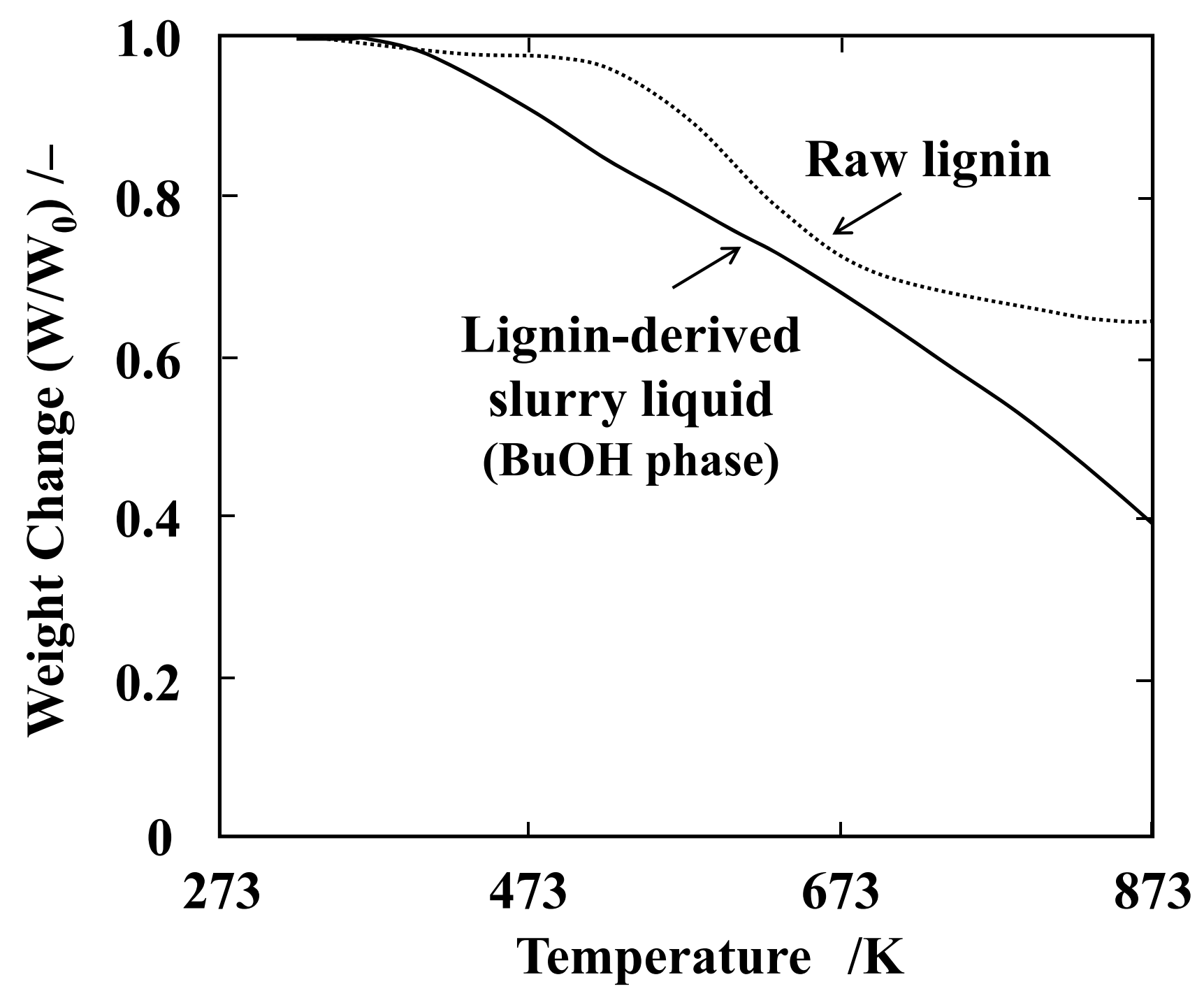

Figure 7. Results of TGA analysis of lignin-derived slurry liquid (BuOH phase). $\mathrm{W}_{0}$ : The weight after holding at $323 \mathrm{~K}$ for $1 \mathrm{~h}$ under $\mathrm{N}_{2}$ atmosphere. 
(a) Phenethyl phenyl ether

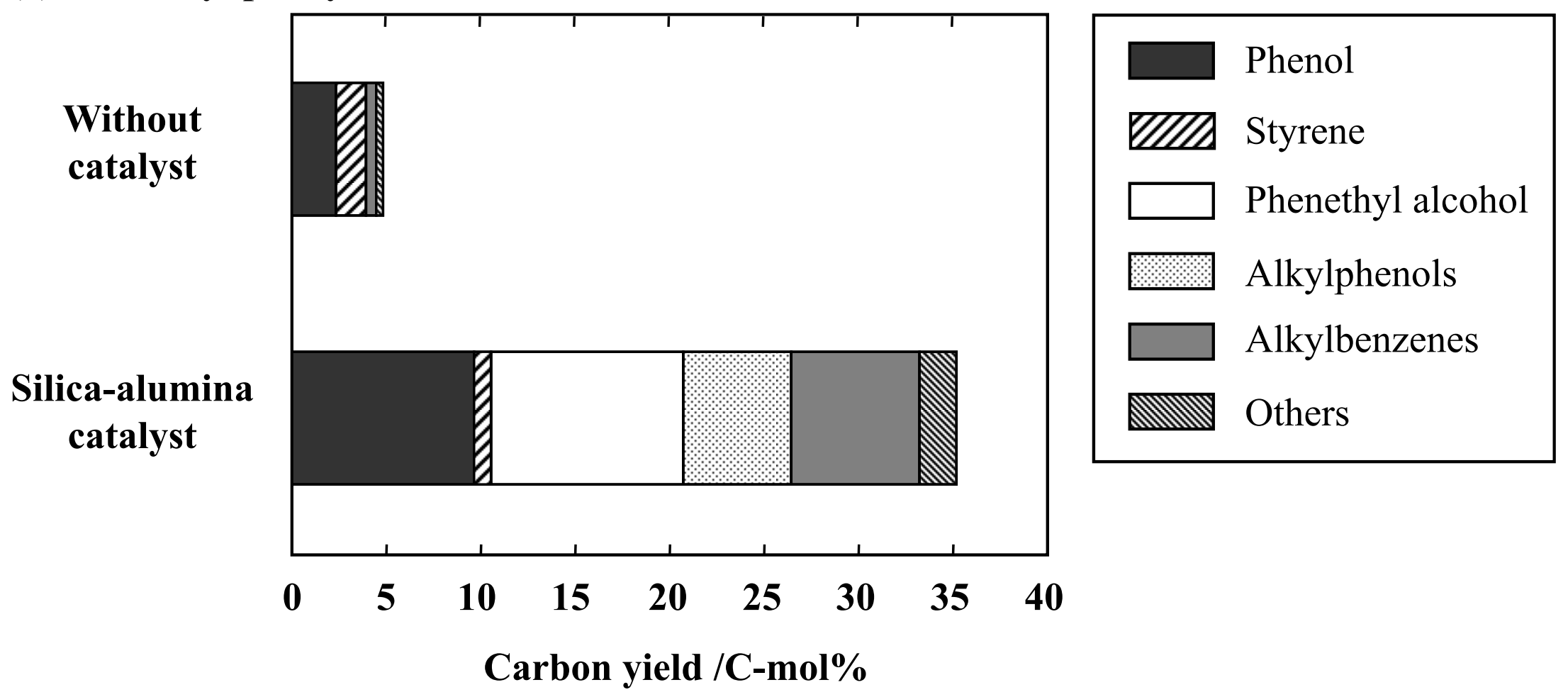

Figure 8. Yields of the identified products by GC after the reaction of model compounds: (a) phenethyl phenyl ether, (b) 2-methoxy-4-methylphenol.

Reaction conditions: $\mathrm{H}_{2} \mathrm{O} / \mathrm{BuOH}=4, \mathrm{~T}=623 \mathrm{~K}$, reaction time $=2 \mathrm{~h}$. 
(b) 2-Methoxy-4-methyphenol

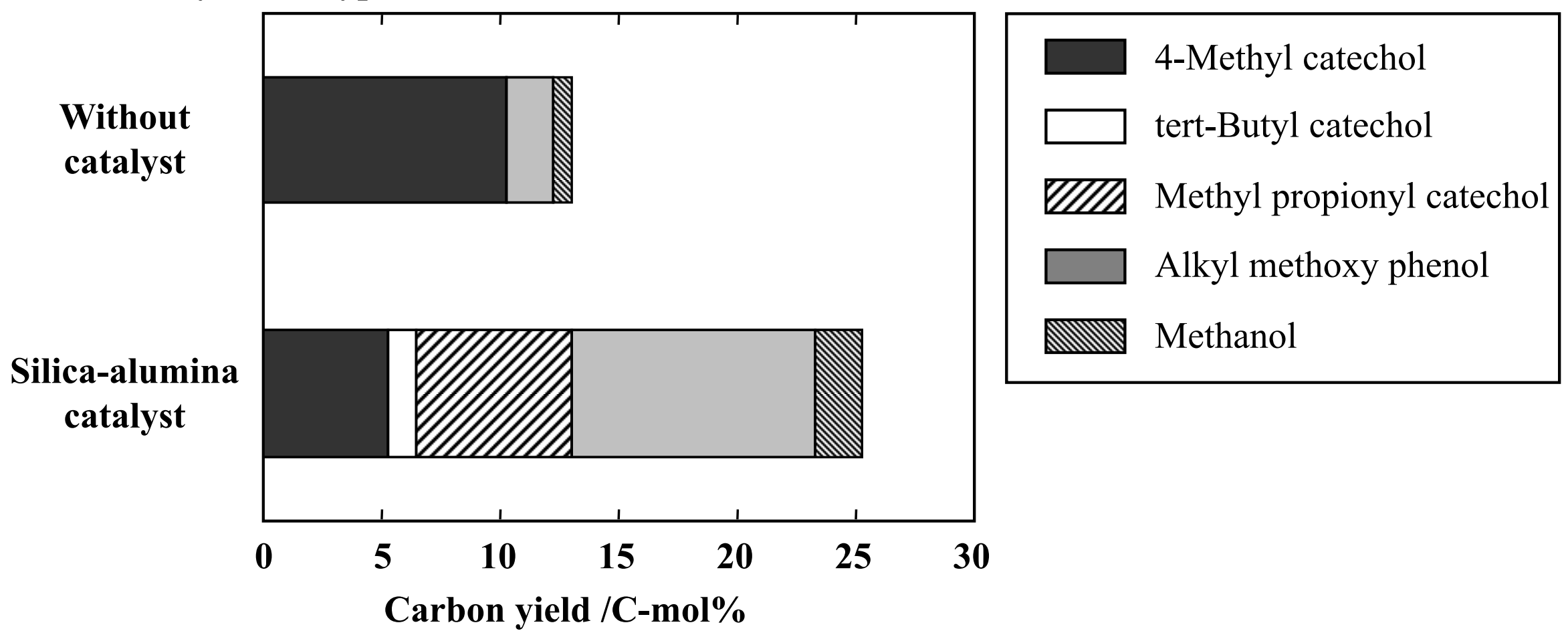

Figure 8. Yields of the identified products by GC after the reaction of model compounds: (a) phenethyl phenyl ether, (b) 2-methoxy-4-methylphenol.

Reaction conditions: $\mathrm{H}_{2} \mathrm{O} / \mathrm{BuOH}=4, T=623 \mathrm{~K}$, reaction time $=2 \mathrm{~h}$. 


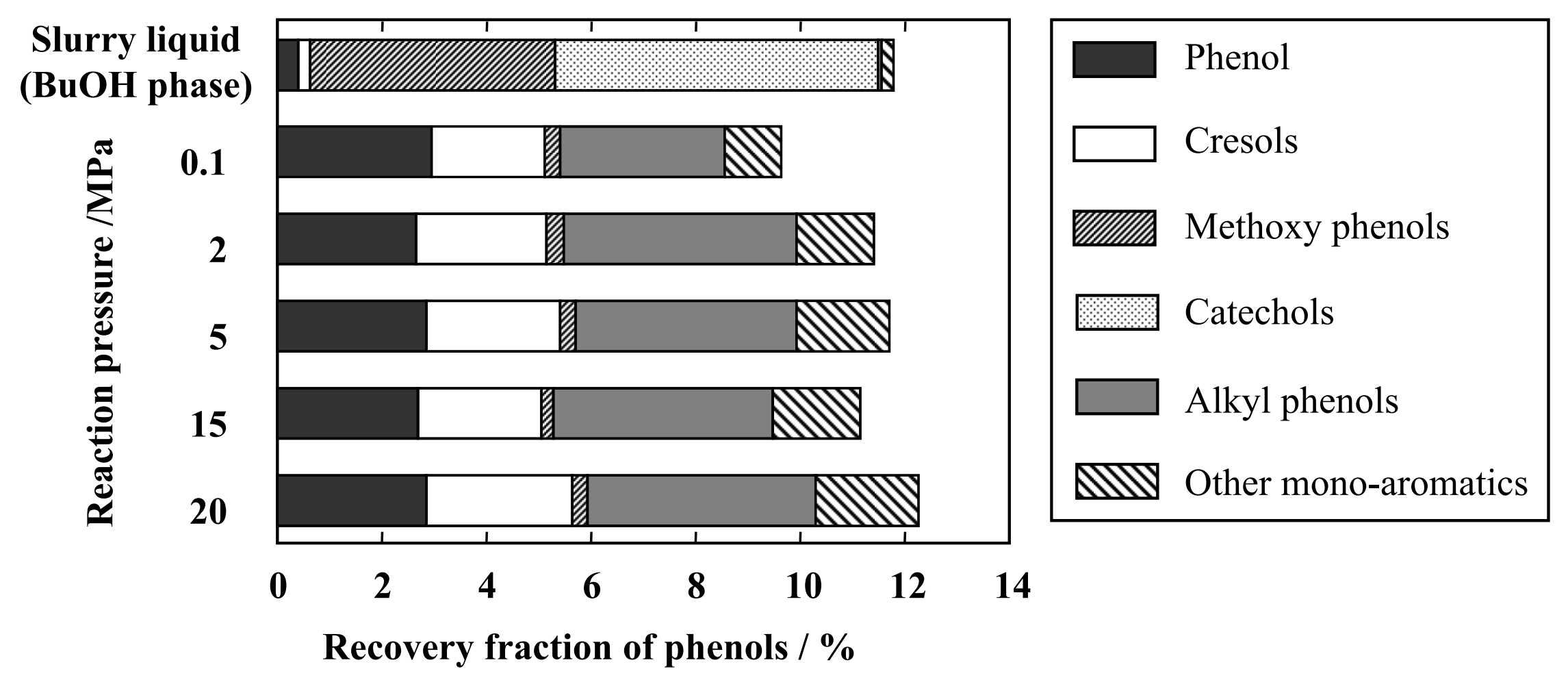

Figure 9. Effect of reaction pressure on the recovery fraction of phenols after the reaction of the slurry liquid. Reaction conditions: $\mathrm{CeO}_{2}-\mathrm{ZrO}_{2}-\mathrm{Al}_{2} \mathrm{O}_{3}-\mathrm{FeO}_{\mathrm{X}}, W / F=0.5 \mathrm{~h}, \mathrm{~T}=673 \mathrm{~K}$, reaction time $=2 \mathrm{~h}$. 


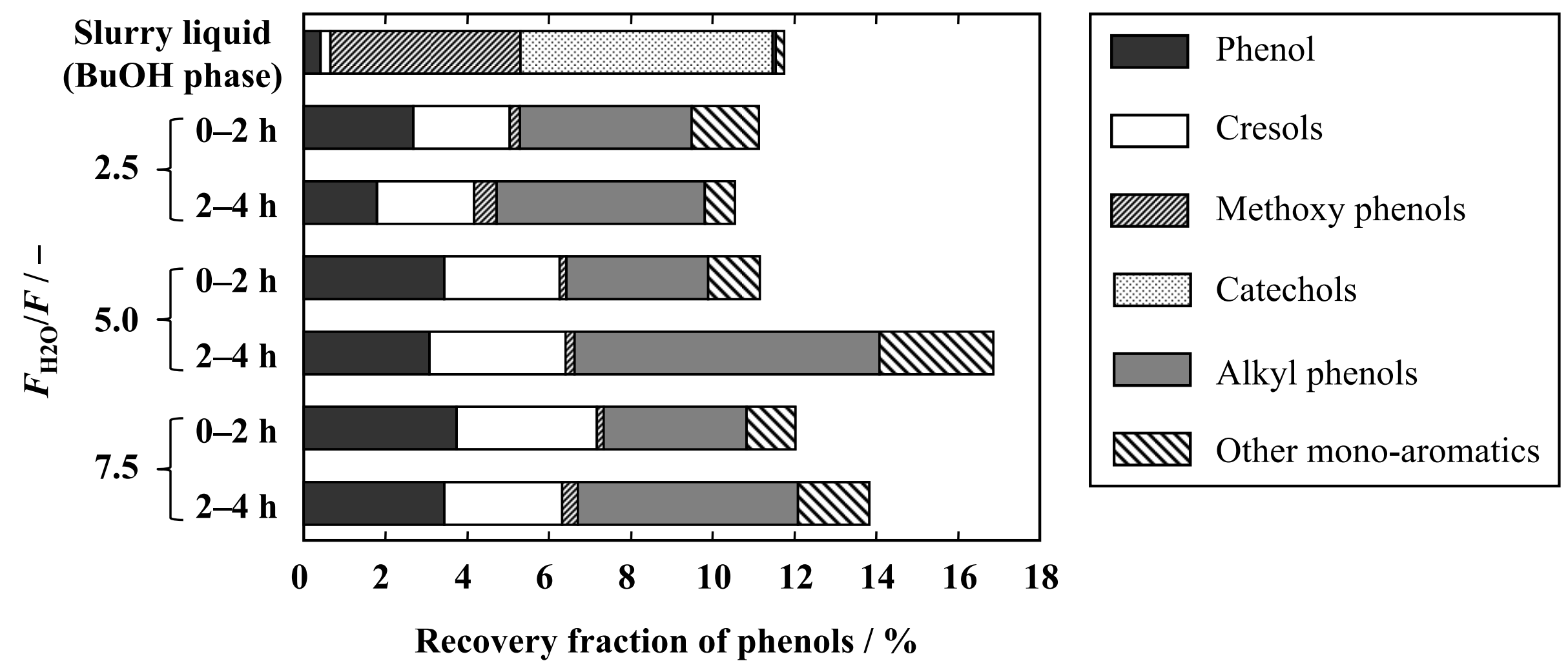

Figure 10. Effect of $F_{\mathrm{H} 2 \mathrm{O}} / F$ value on the recovery fraction of phenols after the reaction of the slurry liquid. Reaction conditions: $\mathrm{CeO}_{2}-\mathrm{ZrO}_{2}-\mathrm{Al}_{2} \mathrm{O}_{3}-\mathrm{FeO}_{\mathrm{X}}, W / \mathrm{F}=0.5 \mathrm{~h}, P=15 \mathrm{MPa}, T=673 \mathrm{~K}$, reaction time $=2-4 \mathrm{~h}$. 


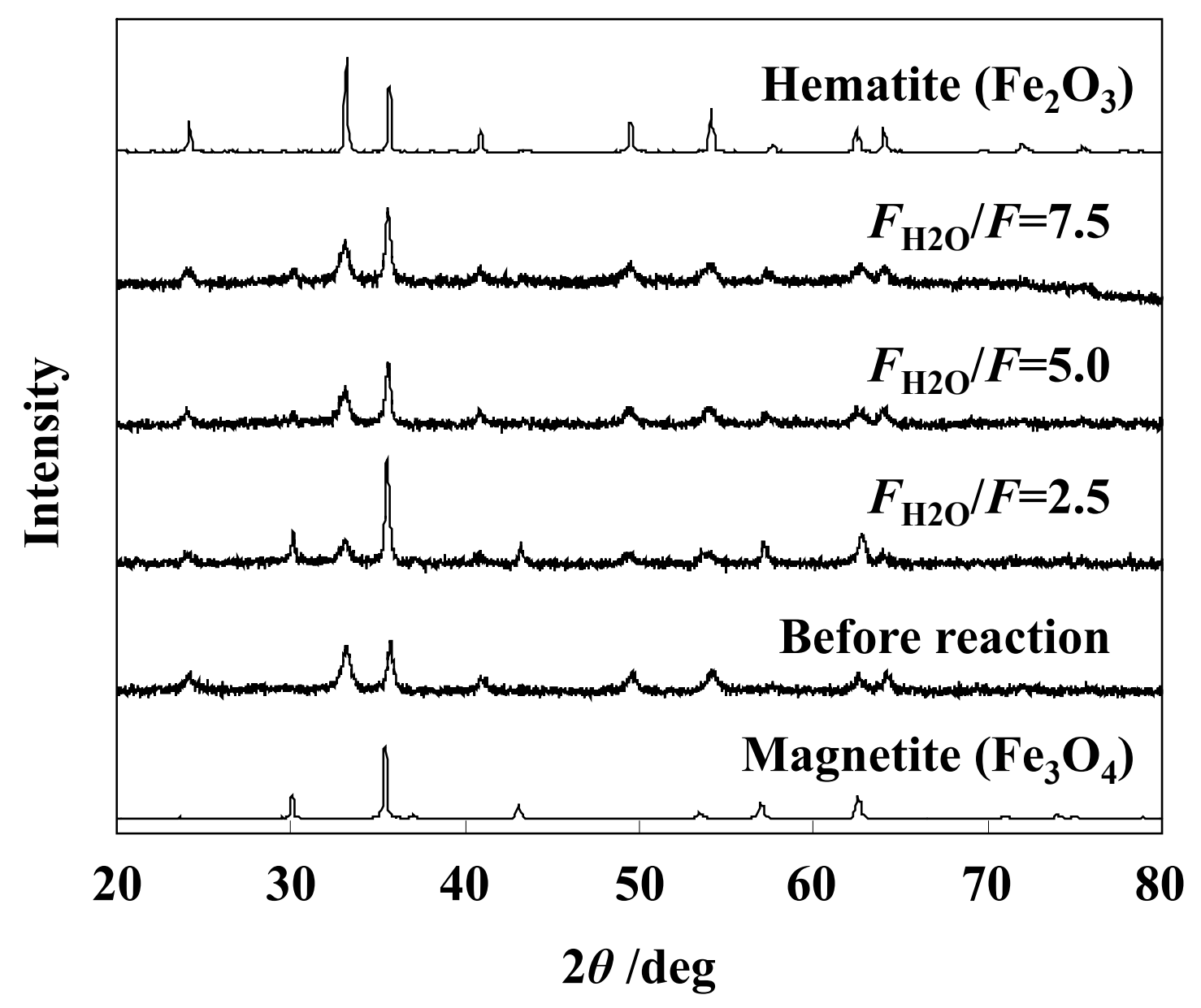

Figure 11. $\mathrm{XRD}$ patterns of $\mathrm{CeO}_{2}-\mathrm{ZrO}_{2}-\mathrm{Al}_{2} \mathrm{O}_{3}-\mathrm{FeO}_{\mathrm{X}}$ catalysts before and after the reactions of the slurry liquid at different values of $\mathrm{F}_{\mathrm{H} 2 \mathrm{O}} / \mathrm{F}$. Reaction conditions: $W / F=0.5 \mathrm{~h}, P=15 \mathrm{MPa}$, reaction time $=2 \mathrm{~h}$. 
(a) $\mathrm{CeO}_{2}-\mathrm{ZrO}_{2}-\mathrm{Al}_{2} \mathrm{O}_{3}-\mathrm{FeO}_{\mathrm{X}}$
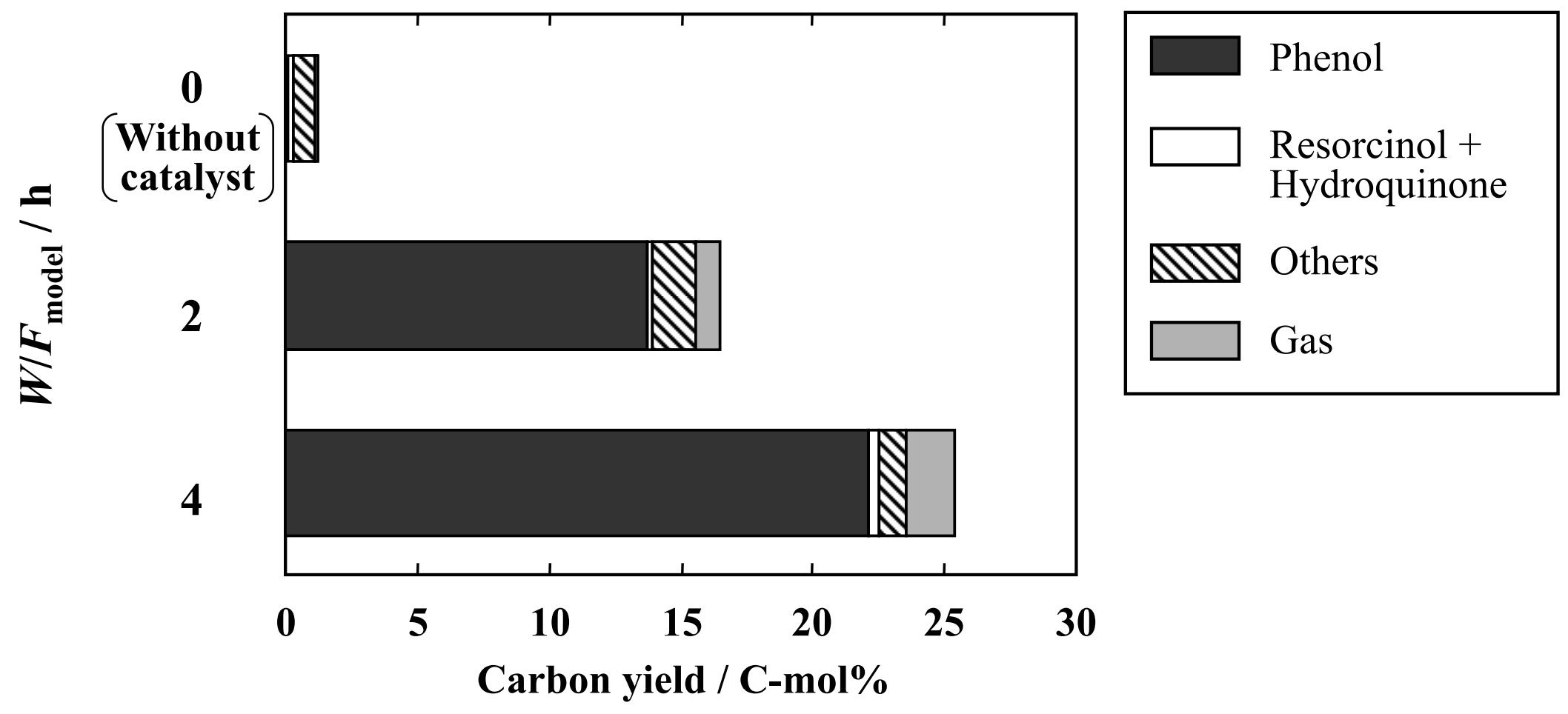

(b) $\mathrm{ZrO}_{2}-\mathrm{FeO}_{\mathrm{X}}$

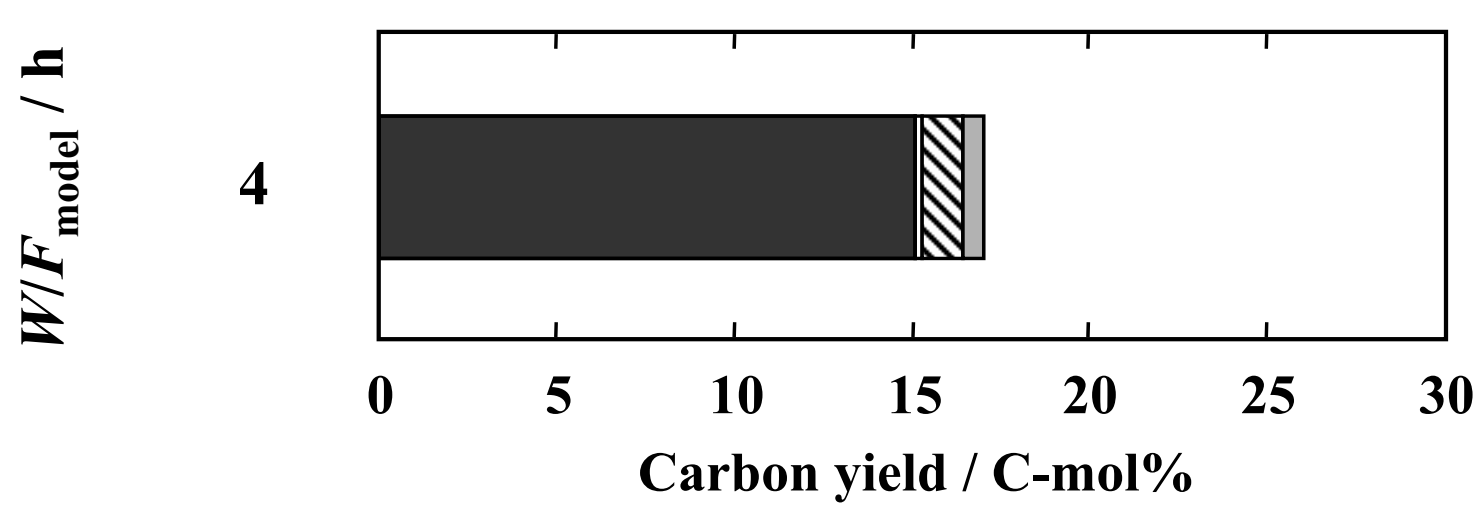

Figure 12. Yields of the detectable products by $\mathrm{GC}$ after the reactions of catechol solution over

(a) $\mathrm{CeO}_{2}-\mathrm{ZrO}_{2}-\mathrm{Al}_{2} \mathrm{O}_{3}-\mathrm{FeO}_{\mathrm{X}}$, (b) $\mathrm{ZrO}_{2}-\mathrm{FeO}_{\mathrm{X}}$

Reaction conditions: $T=673 \mathrm{~K}$,

$P=0.1 \mathrm{MPa}$, reaction time $=2 \mathrm{~h}$. 


\begin{tabular}{|c|c|}
\hline Component & Recovery fraction $/ \%$ \\
\hline Phenol & 0.41 \\
\hline Cresols & 0.23 \\
\hline Alkyl phenols & 0.08 \\
\hline Butyl phenol & 0.08 \\
\hline Methoxy phenols & 4.64 \\
\hline Guaiacol & 2.59 \\
\hline Methyl guaiacol & 0.92 \\
\hline Ethyl guaiacol & 0.53 \\
\hline Vanillin & 0.12 \\
\hline Other methoxy phenols & 0.49 \\
\hline Catechols & 6.14 \\
\hline Catechol & 1.50 \\
\hline Methyl benzenediol & 0.86 \\
\hline Dimethyl benzenediol & 1.68 \\
\hline Ethyl benzenediol & 1.01 \\
\hline Propyl benzenediol & 1.11 \\
\hline Other mono-aromatics & 0.21 \\
\hline Methoxy phenyl acetone & 0.21 \\
\hline Total & 11.7 \\
\hline
\end{tabular}

Table 1. Recovery fraction of components of phenols in the $\mathrm{BuOH}$ phase of the slurry liquid. Reaction conditions: $\mathrm{H}_{2} \mathrm{O} / \mathrm{BuOH}=4$, silica-alumina, $T=623 \mathrm{~K}$, reaction time $=2 \mathrm{~h}$. 
(a) Phenethyl phenyl ether

\begin{tabular}{l|cc}
\hline \multicolumn{1}{c|}{ Components } & \multicolumn{2}{c}{ Carbon yield /C-mol\% } \\
& Without catalyst & Silica-alumina \\
\hline Unreacted model compound & 87.9 & 47.1 \\
Identified products by GC & 4.8 & 35.1 \\
Unidentified+undetectable products by GC & 7.3 & 16.3 \\
Coke on the catalyst & - & 1.5 \\
\hline Total & 100 & 100 \\
\hline
\end{tabular}

Table 2. Product yields after the reaction of model compounds:

(a) phenethyl phenyl ether, (b) 2-methoxy-4-methylphenol.

Reaction conditions: $\mathrm{H}_{2} \mathrm{O} / \mathrm{BuOH}=4, T=623 \mathrm{~K}$, reaction time $=2 \mathrm{~h}$. 
(b) 2-Methoxy-4-methylphenol

\begin{tabular}{l|cc}
\multicolumn{1}{c|}{ Components } & \multicolumn{2}{c}{ Carbon yield /C-mol\% } \\
& Without catalyst & Silica-alumina \\
\hline Unreacted model compound & 61.7 & 36.8 \\
Identified products by GC & 13.0 & 25.2 \\
Unidentified+undetectable products by GC & 25.3 & 36.3 \\
Coke on the catalyst & - & 1.7 \\
\hline Total & 100 & 100 \\
\hline
\end{tabular}

Table 2. Product yields after the reaction of model compounds:

(a) phenethyl phenyl ether, (b) 2-methoxy-4-methylphenol.

Reaction conditions: $\mathrm{H}_{2} \mathrm{O} / \mathrm{BuOH}=4, T=623 \mathrm{~K}$, reaction time $=2 \mathrm{~h}$. 


\begin{tabular}{|c|c|c|c|c|c|}
\hline \multirow{3}{*}{ Components of solid products } & \multicolumn{5}{|c|}{ Carbon yield /C-mol\% } \\
\hline & \multicolumn{5}{|c|}{ Pressure /MPa } \\
\hline & 0.1 & 2 & 5 & 15 & 20 \\
\hline [ Front of the catalyst bed & 19.8 & 17.7 & 17.6 & 11.0 & 2.8 \\
\hline Residue $\{$ Reactor & 0.3 & 0.0 & 0.1 & 1.0 & 0.4 \\
\hline Behind of the catalyst bed & 5.0 & 7.6 & 7.6 & 7.5 & 6.5 \\
\hline Coke on the catalyst & 13.6 & 9.9 & 9.3 & 8.7 & 12.3 \\
\hline Total & 38.7 & 35.2 & 34.7 & 28.2 & 21.9 \\
\hline
\end{tabular}

Table 3. Effect of reaction pressure on the yield of solid products after the reaction of the slurry liquid. Reaction conditions: $\mathrm{CeO}_{2}-\mathrm{ZrO}_{2}-\mathrm{Al}_{2} \mathrm{O}_{3}-\mathrm{FeO}_{\mathrm{X}}, W / F=0.5 \mathrm{~h}, T=673 \mathrm{~K}$, reaction time $=2 \mathrm{~h}$. 
(a) Catechol

\begin{tabular}{l|ccccc}
\hline \multicolumn{1}{c|}{ Components } & Catalyst & \multicolumn{2}{c}{$\mathrm{CeO}_{2}-\mathrm{ZrO}_{2}-\mathrm{Al}_{2} \mathrm{O}_{3}-\mathrm{FeO}_{\mathrm{X}}$} & \multicolumn{2}{c}{$\mathrm{ZrO}_{2}-\mathrm{FeO}_{\mathrm{X}}$} \\
& $\mathrm{W} / \mathrm{F}_{\text {model }} / \mathrm{h}$ & 0 & 2 & 4 & 4 \\
\hline Unreacted model compound $/ \mathrm{C}-\mathrm{mol} \%$ & & 101 & 85.6 & 58.3 & 80.4 \\
Detectable products by GC $/ \mathrm{C}-\mathrm{mol} \%$ & & 1.3 & 16.5 & 25.4 & 16.9 \\
Coke on the catalyst /C-mol\% & & - & 8.4 & 14.4 & 7.9 \\
\hline Total /C-mol\% & 102 & 111 & 98.1 & 105 \\
\hline
\end{tabular}

(b) Phenol

\begin{tabular}{l|cc}
\hline \multicolumn{1}{c|}{ Components } & Catalyst \\
& W/F $\mathrm{F}_{\text {model }} / \mathrm{h}$ & $\mathrm{CeO}_{2}-\mathrm{ZrO}_{2}-\mathrm{Al}_{2} \mathrm{O}_{3}-\mathrm{FeO}_{\mathrm{X}}$ \\
\hline Unreacted model compound $/ \mathrm{C}-\mathrm{mol} \%$ & 93.9 \\
Detectable products by GC $/ \mathrm{C}-\mathrm{mol} \%$ & 1.4 \\
Coke on the catalyst /C-mol\% & 4.3 \\
\hline Total /C-mol\% & 99.6 \\
\hline
\end{tabular}

Table 4. Product yields after the reaction of the solution of model compounds: (a) catechol, (b) phenol. Reaction conditions: $T=673 \mathrm{~K}, P=0.1 \mathrm{MPa}$, reaction time $=2 \mathrm{~h}$. 

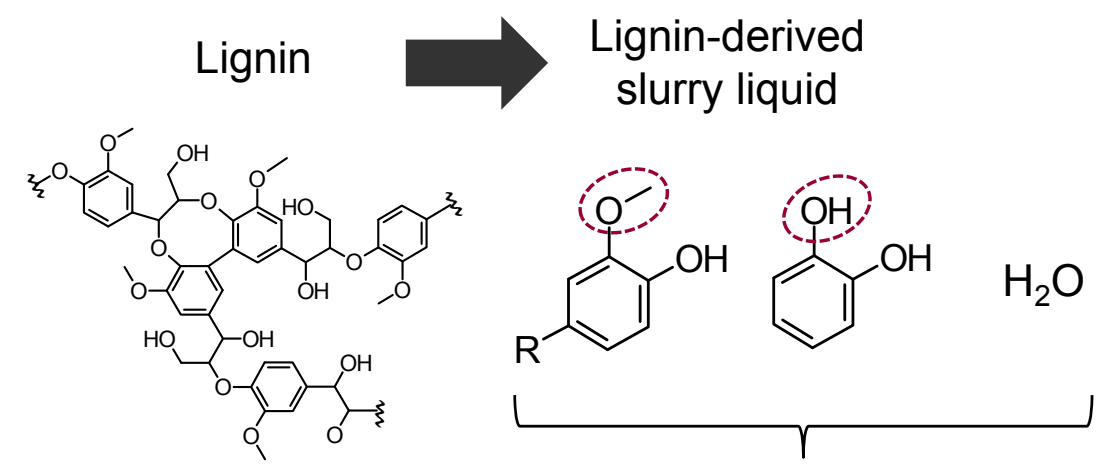

$0.1 \mathrm{MPa}$

High pressure

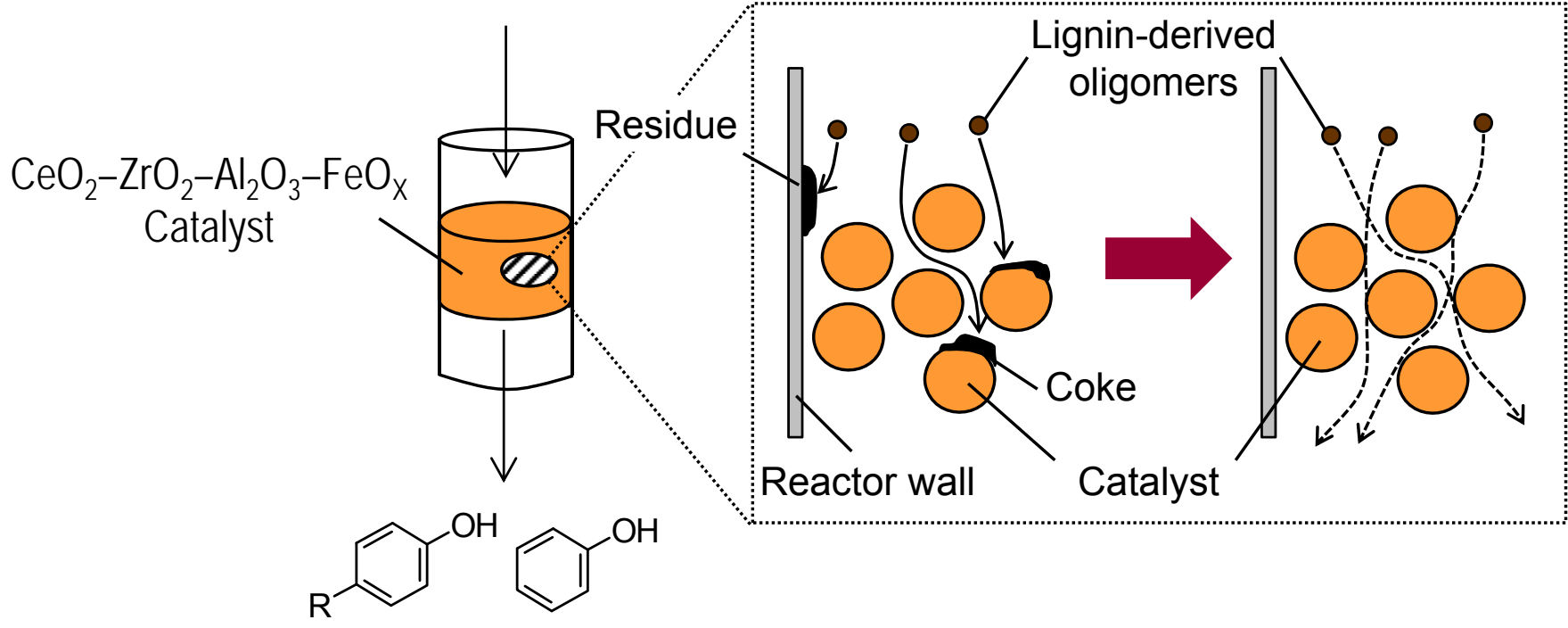

Graphical Abstract 